\title{
Pengaruh Pendidikan Kesehatan terhadap Persiapan Menghadapi Menarche pada Siswa SD 060963 Tahun 2020
}

\author{
Saddiyah Rangkuti \\ Program Studi Kebidanan, Universitas Haji Sumatera Utara
}

\begin{tabular}{l}
\hline Info Artikel \\
\hline Article history: \\
Diterima 01-06-2021 \\
Revisi 20-06-2021 \\
Disetujui 03-07-2021 \\
\hline
\end{tabular}

\section{Kata kunci:}

Pendidikan kesehatan, Menarche,

Siswa.

\begin{abstract}
A B S T R A K
Masa pubertas merupakan satu tahap perkembangan yang ditandai dengan kematangan organ seksual dan menuju tercapainya kemampuan reproduksi, pada perempuan ditandai dengan Haid. Remaja putri yang telah memasuki masa pubertas akan mengalami menarche, tujuan penelitian Pengaruh pendidikan kesehatan terhadap persiapan menghadapi menghadapi menarche pada siswa SD 060963 Tahun 2020”. Jenis penelitian yang digunakan dalam penelitian ini adalah jenis penelitian Pre-eksperimental design, menggunakan One Group pre-test and post-test design,, Populasi dalam penelitian ini adalah seluruh siswa kelas V yang berjumlah 58 siswa, Teknik Purposive Sampling Jadi jumlah sampel dalam penelitian ini adalah sebanyak 20 siswa kelas V. Analisa bivariat Uji Wilcoxon digunakan untuk melihat pengaruh antara dua variabel dengan derajat kepercayaan $95 \%$. Ada pengaruh atau perbedaan yang signifikan antara pendidikan kesehatan terhadap persiapan menghadapi menghadapi menarche pada siswa SD 060963 Tahun 2020, dengan nilai $\mathrm{p}$ $(0,000)<\alpha(0,05)$. Hasil ini membuktikan bahwa pendidikan kesehatan dapat memberikan pengaruh yang baik terhadap persiapan menghadapi menghadapi menarche pada siswa SD 060963 Tahun 2020. Diharapkan bagi peneliti selanjutnya dapat meningkatkan pengetahuan sekaligus memberikan informasi tentang pendidikan kesehatan tentang persiapan menghadapi menghadapi menarche pada siswa SD dengan metode dan media yang berbeda. Sehingga memberikan kemudahan kepada penlitian selanjutnya dan memberikan hasil yang lebih baik.
\end{abstract}

\section{Koresponden Penulis:}

Saddiyah Rangkuti,

Program Studi Kebidanan, Universitas Haji Sumatera Utara,

Jl. Rumah Sakit H., Medan Estate, Kec. Percut Sei Tuan, Kabupaten Deli Serdang, Sumatera Utara 20371.

Email: saddiyahrangkuti76@gmail.com

\section{PENDAHULUAN}

Masa pubertas merupakan satu tahap perkembangan yang ditandai dengan kematangan organ seksual dan menuju tercapainya kemampuan reproduksi, pada perempuan ditandai dengan Haid. Remaja putri yang telah memasuki masa pubertas akan mengalami menarche (Janiwarti \& Pieter, 2017). Menarche didefenisikan sebagai menstruasi pertama yang biasa terjadi dalam rentang usia 10-16 tahun, yaitu berupa perdarahan periodik dan siklik dari uterus disertai pengelupasan (deskuamasi) endometrium (Proverawati \& Misaroh, 2017).

Menarche merupakan menstruasi pertama yang biasa terjadi dalam rentang usia 10-16 tahun atau pada masa awal remaja di tengah masa pubertas sebelum memasuki masa reproduksi (Proverawati, 2017). Menarche biasanya rata-rata terjadi pada umur 11-12 tahun. Dalam dasawarsa terakhir ini usia menarche telah bergeser ke usia yang lebih muda, mungkin hal ini disebabkan oleh makin baiknya nutrisi dan kesehatan pada generasi sekarang (Wiknjosastro, 2017).

Data demografi menunjukkan bahwa penduduk di dunia jumlah populasi remaja merupakan populasi yang besar dari penduduk dunia. Menurut World Health Organization dalam Soetjiningsih (2017) yang di kutip lagi oleh Wahyu, Dkk. (2010) sekitar seperlima dari penduduk dunia terdiri dari 
remaja berumur 10- 19 tahun. Sekitar sembilan ratus juta berada dinegara sedang berkembang Menurut WHO batasan usia remaja yaitu antara umur 10-19 tahun. Di Indonesia, remaja usia 10- 19 tahun berjumlah sekitar 43 jiwa atau 19,61\% dari jumlah penduduk (Depkes RI, 2016). Sedangkan untuk remaja usia 10-19 tahun (WHO, 2017), berjumlah 44 juta atau 21\%. Pada tahun 2008, jumlah remaja di Indonesia mencapai 62 juta jiwa (Prastika, 2016).

Kejadian pubertas pada remaja putri bervariasi dipengaruhi oleh keturunan, bangsa, lingkungan, ras atau suku bangsa, faktor iklim, cara hidup, keterpaparan terhadap media masa orang dewasa dan lingkungan. Badan yang lemah atau penyakit yang mendera seorang anak gadis umpamanya, bisa memperlambat tibanya menstruasi. Selanjutnya rangsangan-rangsangan kuat dari luar, seperti film-film seks ( blue films ), buku-buku bacaan dan majalah bergambar seks, godaan dan rangsangan dari kaum pria, pengamatan langsung terhadap perbuatan seksual. Semua itu tidak hanya mengakibatkan memuncaknya atau semakin panasnya reaksi-reaksi seksual saja, akan tetapi juga mengakibatkan kematangan seksual yang lebih pada diri anak, namun semakin muda usia anak perempuan tersebut maka akan semakin belum siap menerima peristiwa menstruasi (Kartono, 2016)

Stanley Hall seorang bapak Pelopor Psikologi Perkembangan Remaja mengemukakan bahwa masa remaja dianggap sebagai masa "topan-badai dan stres" (storm and stress) sehingga tak aneh jika melihat usia pubertas ini menjadikan remaja gampang marah dan mudah tersinggung (Mansur \& Budiarti, 2017).

Di Negara Eropa usia rata-rata menarche terus menurun sekitar empat bulan pada setiap decade dalam abad ini. Di Amerika Serikat, sekitar 95\% wanita remaja mempunyai tanda-tanda pubertas dengan menarche terjadi antara usia 8-13 tahun dan umur rata-rata 12,5 tahun yang diiringi dengan pertumbuhan fisik saat menarche. Di Maharashtra, India rata-rata usia menarche pada anak perempuan adalah 12,5 tahun. Di Netherlands menunujukkan pada tahun 1985 dan 2016, usia pubertas rata-rata telah berkurang dari 11 tahun menjadi 10.7 tahun. $24,95 \%$ menarche dini $(10-11$ tahun), 64,77\% menarche ideal (12- 13 tahun) dan 10,30\% menarche terlambat (14-15 tahun) (Pulungan, 2016).

Di Indonesia gadis remaja pada waktu menarche bervariasi antara 14-16 tahun menurun menjadi 10-16 tahun dan rata-rata menarche 12,5 tahun, usia menarche lebih dini di daerah perkotaan dari pada yang tinggal di Desa. (Marizal, 2015 dalam Ramadanus, 2008) yang dikutip lagi oleh (Yulia, 2016) mengemukakan usia menarche di Sumatra Barat 12.59 tahun dan di kota Padang ditemukan usia menarche 12,2 tahun. Usia menarche yang terlalu cepat pada sebagian remaja putri dapat menimbulkan keresahan secara mental (Sarwono, 2016).mengatakan rata-rata usia menarche remaja di perkotaan adalah 11,93 tahun sedangkan remaja di pedesaan rata-rata usia menarche 13,08 tahun, berarti datangnya menarche remaja perkotaan lebih awal dibandingkan dengan remaja di pedesaan (Yulia, 2016).

Departemen Kesehatan Republik Indonesia melaporkan terjadi penurunan usia menarche di Indonesia. Berdasarkan hasil RISKESDAS tahun 2010 dikutip dari Laadjim (2017) terdapat $5.2 \%$ anakanak di 17 provinsi Indonesia telah memasuki usia menarche di bawah usia 12 tahun.

Pendidikan kesehatan adalah aplikasi atau penerapan pendidikan di dalam bidang kesehatan. Hasil (output) yang diharapkan dari suatu pendidikan kesehatan adalah perilaku kesehatan, atau perilaku untuk memelihara dan meningkatkan kesehatan yang kondusif (Notoatmodjo, 2017).

Menarche yang tidak disertai dengan pemberian informasi-informasi yang jelas, benar dan bisa menentramkan hati akan mengakibatkan munculnya gejala-gejala patologis misalnya rasa ketakutan, kecemasan konflik-konflik batiniah dan gangguan pusing, mual, disminorhea, haid tidak teratur dan berbagai macam gangguan lainnya, sedangkan masalah fisik yang mungkin timbul dari kurangnya pengetahuan itu adalah kurangnya personal hygiene sehingga dapat beresiko untuk terjadinya infeksi pada saluran kemih (ISK) dan kanker leher rahim (Proverawati, 2017). Menarche memerlukan penyesuaian diri yang kuat, baik positif maupun negatif yaitu sikap menerima secara biologis menjalani fungsi kewanitaannya (Manuaba, 2017).

Seorang anak gadis telah dipersiapkan akan kedatangan menstruasi, hal ini biasa menjadi saat yang mengecewakan baginya. Anak-anak perempuan yang tidak mengenal tubuh mereka dan proses reproduksi dapat mengira bahwa menstruasi merupakan bukti adanya penyakit atau bahkan hukuman akan tingkah laku yang buruk. Anak-anak perempuan yang tidak diajari untuk menganggap

JURKESMAS : Jurnal Kesehatan Masyarakat, Vol. 1, No. 1, Juli 2021: 1 - 6 
menstruasi sebagai fungsi tubuh nomal dapat mengalami rasa malu yang amat dalam dan perasaan kotor saat menstruasi pertama mereka. Hal tersebut terjadi karena tidak mengetahui apaapa tentang menstruasi, dan mengira bahwa menstruasi merupakan bukti adanya penyakit atau bahkan yang sedang mengalami pendarahan yang dapat menyebabkan kematian (Darvill \& Powell, 2016).

Remaja putri membutuhkan informasi tentang prosres menstruasi dan kesehatan selama menstruasi. Remaja putri akan mengalami kesulitan dalam menghadapi menstruasi yang pertama sekali terjadi jika sebelumnya ia belum pernah mengetahui atau membicarakan baik dengan teman sebaya atau dengan ibu mereka. Pada umumnya, gadis remaja belajar tentang haid dari ibunya, tetapi tidak semua ibu memberikan informasi yang memadai kepada putrinya. Sebahagian lagi remaja putri enggan membicarakan secara terbuka kepada siapa saja sampai anak gadisnya mengalami haid pertama (Jones, 2017).

Berdasarkan penelitian Nurul Fatimah tahun 2016 dengan judul pengaruh pendidikan kesehatan metode peer group tentang menstruasi terhadap kesiapan menghadapi menarche pada siswi sd kelas v di sd pundenarum di kecamatan karangawen kabupaten demak, didapatkan hasil penelitian nilai $\mathrm{P}-$ Value $=0,000$, sehingga dapat disimpulkan bahwa ada pengaruh pendidikan kesehatan metode peer tentang menstruasi terhadap kesiapan menghadapi menarche pada siswi SD kelas V di SD Pundenarum 1 Kecamatan Karangawen Kabupaten Demak tahun 2016.

Penelitian yang dilakukan oleh Vino Rika Nofia tahun 2018 dengan judul penelitian pengaruh pendidikan kesehatan tentang menarche terhadap kecemasan menghadapi menarche pada siswa kelas 4-6 di sdn 24 ujung gurun kecamatan padang barat dari hasil uji statistik terdapat perbedaan yang bermakna antara nilai tingkat kecemasan sebelum dan sesudah diberikan pendidikan kesehatan dengan nilai signifikan 0,000. Nilai tersebut menunjukkan bahwa terdapat perbedaan antara sebelum dengan sesudah diberikan pendidikan kesehatan tentang menarche terhadap kecemasan menghadapi menarche pada siswi kelas 4-6 di SD N 24 Ujung Gurun Kecamatan Padang Barat Tahun 2015.

Berdasarkan survey awal yang dilakukan pada tanggal 28 April 2020 melalui wawancara, dengan jumlah siswa keseluruhan kelas $\mathrm{V}$ yaitu 68 siswa yang dibagi menjadi 2 kelas yaitu kelas $\mathrm{A}$ dan kelas B, jumlah siswa laki-laki yaitu 29 siswa, sedangkan siswa perempuan berjumlah 39 siswa, rata-rata umur siswi perempuan yang berumur 9 tahun 2 siswa, berumur 10 tahun 33 siswa, berumur 11 tahun 4 siswa, sedangkan siswa yang sudah mengalami menstruasi berjumlah 4 siswa yang berumur 10 tahun.studi pendahuluan dilakukan dengan wawancara terhadap siswi SD kelas $\mathrm{V}$ berjumlah 10 orang, tentang menstruasi ternyata dari 10 siswi hanya 2 orang yang mampu menjawab pendidikan kesehatan tentang menstruasi dengan benar dan menganggap bahwa menstruasi hal yang wajar, sedangkan 8 siswi belum mengerti tentang menstruasi, dan mereka mengatakan tidak siap dan takut menstruasi, alasan mereka tidak tahu karena mereka tidak pernah mendapatkan pendidikan kesehatan tentang kesipan menghadapi menarceh.

\section{METODE PENELITIAN}

Lokasi Penelitian ini dilakukan di SD 060963 Medan terletak di Jl. Hidayah Kel. Belawan Sicanang. Batasan wilayah SD 060963. SD 060963 Medan memiliki Sarana yang ada diruang UKS adalah seperti: meja obat/ meja alat kedokteran, bed pemeriksa, meja dan kursi petugas UKS, sekat pembatas/ gurden, Lemari obat atau kotak obat, alat pengukur tinggi badan, wastafel atau waskop, embar plastik untuk menampung kotoran bekas, pembalut dan lain-lain.

\section{HASIL DAN PEMBAHASAN}

\subsection{Hasil}

\section{Analisa Univariat}

Karakteristik responden di SD 060963 Tahun 2020 pada penelitian ini dikelompokkan berdasarkan umur, dan kelas. Karakteristik resonden diuraikan dalam tabel 1 sebagai berikut:

Tabel 1. Karakteristik Responden di SD 060963 Tahun 2020

\begin{tabular}{clcc}
\hline No & \multicolumn{1}{c}{ Data Demografi } & Frekuensi & Presentase (\%) \\
\hline 1 & Umur & 6 & 30,0 \\
& 10 tahun & 8 & 40,0 \\
& 11 tahun & 6 & 30,0 \\
\hline
\end{tabular}




\begin{tabular}{llccc}
\hline & Jumlah & 20 & 100 \\
\hline 2 & Kelas & & 6 & 30,0 \\
IV & & 8 & 40,0 \\
V & & 6 & 30,0 \\
VI & Jumlah & 20 & 100 \\
\hline
\end{tabular}

Berdasarkan tabel 1 di atas sebagian besar siswa SD yang menjadi responden mayoritas berusia 11 tahun sebanyak 8 responden (40,0\%) dan duduk di kelas V sebanyak 8 responden (40,0\%).

Persiapan Menghadapi Menarche Sebelum Diberikan Pendidikan Kesehatan Menarche Pada Siswa SD 060963 Tahun 2020. Data persiapan menghadapi menarche sebelum diberikan pendidikan kesehatan menarche pada siswa SD 060963 Tahun 2020 dapat dilihat pada tabel 2 berikut :

Tabel 2. Persiapan Menghadapi Menarche Sebelum Diberikan Pendidikan Kesehatan Menarche Pada Siswa SD 060963 Tahun 2020

\begin{tabular}{ccc}
\hline $\begin{array}{c}\text { Persiapan Menghadapi } \\
\text { Menghadapi Menarche (Pre tes) }\end{array}$ & Frekuensi & $\%$ \\
\hline Baik & 3 & 15,0 \\
Cukup & 8 & 40,0 \\
Kurang & 9 & 45,0 \\
\hline Jumlah & 20 & 100 \\
\hline
\end{tabular}

Berdasarkan tabel 2 di atas menunjukkan bahwa persiapan menghadapi menarche sebelum diberikan pendidikan kesehatan menarche pada siswa SD 060963 Tahun 2020 mayoritas kurang yaitu sebanyak 9 responden $(45,0 \%)$.

Persiapan Menghadapi Menarche Sesudah Diberikan Pendidikan Kesehatan Menarche Pada Siswa SD 060963 Tahun 2020. Data persiapan menghadapi menarche sesudah diberikan pendidikan kesehatan menarche pada siswa SD 060963 Tahun 2020 dapat dilihat pada tabel 3 berikut :

Tabel 3. Persiapan Menghadapi Menarche Sesudah Diberikan Pendidikan Kesehatan Menarche Pada Siswa SD 060963 Tahun 2020

\begin{tabular}{ccc}
\hline Persiapan Menghadapi & Frekuensi & $\%$ \\
Menghadapi Menarche (Post tes) & 8 & 40,0 \\
Baik & 11 & 55,0 \\
Cukup & 1 & 5,0 \\
\hline Kurang & 20 & 100 \\
\hline
\end{tabular}

Berdasarkan tabel 3 di atas menunjukkan bahwa persiapan menghadapi menarche sesudah diberikan pendidikan kesehatan menarche pada siswa SD 060963 Tahun 2020 mayoritas cukup siap yaitu sebanyak 11 responden $(55,0 \%)$.

Hasil uji statistik pengaruh pendidikan kesehatan terhadap persiapan menghadapi menarche pada siswa SD 060963 Tahun 2020 terdapat pada tabel 4 sebagai berikut :

Tabel 4. Pengaruh Pendidikan Kesehatan Terhadap Persiapan Menghadapi Menarche Pada Siswa SD 060963 Tahun 2020

\begin{tabular}{|c|c|c|c|c|c|}
\hline \multirow{3}{*}{$\begin{array}{c}\text { Persiapan Menghadapi } \\
\text { Menarche }\end{array}$} & \multicolumn{2}{|c|}{ Perlakuan } & \multirow{2}{*}{ Perubahan Ranking } & & \multirow{2}{*}{ p value } \\
\hline & Sebelum & Sesudah & & & \\
\hline & f & f & & $\mathbf{F}$ & \\
\hline - Baik & 3 & 8 & Rangking Positif & 0 & $0001 *$ \\
\hline - Cukup & 8 & 11 & Rangking Negatif & 12 & $0,0011^{*}$ \\
\hline - Kurang & 9 & 1 & Ties & 8 & \\
\hline
\end{tabular}

Keterangan : a) Uji Wilcoxon

Perubahan persiapan menghadapi menghadapi menarche:

1. Ranking Negatif adalah perubahan persiapan sebelum dan sesudah dari kategori 'kurang' menjadi kategori 'cukup dan baik'

2. Ranking Positif adalah perubahan sebelum dan sesudah dari kategori 'baik' menjadi 'cukup' atau 'kurang'

3. Ties artinya tidak terjadi perubahan persiapan sebelum dan sesudah 
Berdasarkan tabel 4 di atas menunjukan persiapan menghadapi menghadapi menarche sebelum dan sesudah diberikan pendidikan kesehatan mengalami perubahan. Persiapan menghadapi menghadapi menarche sebelum diberikan pendidikan kesehatan sebanyak 9 responden masuk dalam kategori kurang dan berkurang menjadi 1 responden sesudah diberikan pendidikan kesehatan. Sedangkan persiapan menghadapi menghadapi menarche pada siswa sebelum diberikan pendidikan kesehatan sebanyak 3 responden masuk dalam kategori baik dan setelah diberikan pendidikan kesehatan, persiapan menghadapi menghadapi menarche bertambah menjadi 8 responden, begitu juga persiapan menghadapi menghadapi menarche yang cukup sebelum diberikan pendidikan kesehatan 8 responden dan sesudah diberikan pendidikan kesehatan menjadi 11 responden.

\subsection{Pembahasan}

Berdasarkan Hasil uji statistic dengan menggunakan Uji Wilcoxon diketahui bahwa nilai $\mathrm{p}$ $(0,001)<\alpha(0,05)$ artinya Ho ditolak, jadi terdapat pengaruh yang signifikan pendidikan kesehatan terhadap persiapan menghadapi menghadapi menarche pada siswa SD 060963 Tahun 2020. Hasil ini membuktikan bahwa pendidikan kesehatan dapat memberikan pengaruh yang baik terhadap persiapan menghadapi menghadapi menarche pada siswa SD 060963 Tahun 2020.

Berdasarkan Hasil uji statistic dengan menggunakan Uji Wilcoxon diketahui bahwa nilai $p$ $(0,001)<\alpha(0,05)$ artinya Ho ditolak, jadi terdapat pengaruh yang signifikan pendidikan kesehatan terhadap persiapan menghadapi menghadapi menarche pada siswa SD 060963 Tahun 2020. Hasil ini membuktikan bahwa pendidikan kesehatan dapat memberikan pengaruh yang baik terhadap persiapan menghadapi menghadapi menarche pada siswa SD 060963 Tahun 2020.

Hasil penelitian ini sejalan dengan penelitian Mukhoirotin (2017) yang menunjukkan bahwa ada pengaruh pendidikan kesehatan terhadap kesiapan siswi dalam menghadapi menarche $(p=0,000)$ pada kelompok perlakuan, sedangkan pada kelompok kontrol yang hanya diberikan booklet menunjukkan tidak ada pengaruh terhadap kesiapan siswi dalam menghadapi menarche. Hal ini disebabkan karena dengan memberikan pendidikan kesehatan kepada siswi dapat dijadikan sarana dalam pemberian informasi kepada individu atau kelompok tentang halhal yang belum diketahui oleh responden. Sehingga siswi dapat lebih memahami secara detail dan rinci mengenai menstruasi dan siswi lebih siap dalam menghadapi menarche. Kelompok kontrol menunjukan tidak ada pengaruh kesiapan siswi sebelum dan sesudah diberikan booklet, akan tetapi terjadi peningkatan kesiapan yaitu sebagian besar kesiapan siswi menjadi cukup siap sebanyak 13 siswi (52\%).

Terbukti di sini bahwa pendidikan kesehatan tentang menarche memang efektif untuk meningkatkan persiapan siswa dalam menghadapi menarche. Hal ini berarti bahwa pendidikan kesehatan mempengaruhi persiapan siswi dalam menghadapi menarche. Oleh karena itu pendidikan kesehatan tentang menarche sebaiknya diberikan secara berkesinambungan oleh institusi tempat pendidikan yang bersangkutan juga guru selaku pendidik, sehingga keberhasilan pendidikan kesehatan tidak hanya terbatas pada perubahan dan pembinaan perilaku saja tapi lebih luas ke arah pengembangan perilaku, yaitu perilaku remaja wanita yang benar berkaitan dengan menstruasi dan kematangan organ-organ reproduksi mereka.

Berdasarkan hal ini maka menurut analisa peneliti terhadap penelitian ini adalah ditemukan bahwa adanya pengaruh antara sebelum dengan sesudah diberikan pendidikan kesehatan tentang menarche terhadap persiapan menghadapi menarche pada siswi di SD 060963 tahun 2020. Hal ini menunjukkan bahwa pendidikan kesehatan akan mempengaruhi terhadap tingkat persiapan menghadapi menarche pada siswi SD tersebut. Dengan demikian agar persiapan menghadapi menarche tentang menarche bisa meningkat atau bahkan mereka tidak lagi merasa cemas maka perlu adanya pemberian pendidikan kesehatan pada siswi SD tersebut. Untuk itu perlu adanya peran dari petugas kesehatan setempat untuk memberikan penyuluhan tentang menarche pada siswi SD tentang menarche. Upaya ini bisa dilakuan melalui kerjasama dengan pihak sekolah melalui program Usaha Kesehatan Sekolah (UKS).

\section{KESIMPULAN}

Pengaruh Pendidikan Kesehatan terhadap Persiapan Menghadapi Menarche pada Siswa SD 060963 Tahun 2020 setelah dilakukan pengujian dengan analisa Univariat dan Uji Statistik memperoleh hasil sebanyak 9 responden (45.0\%) kurang siap, sebanyak 11 responden (55.0\%) cukup 
siap dan ada pengaruh yang signifikan antara pendidikan kesehatan terhadap persiapan menghadapi menarche dengan nilai $\mathrm{p}(0,000)<\alpha(0,05)$.

\section{REFERENSI}

Aulia. 2017. Kupas Tuntas Menstruasi Dari A Sampai Z, Yogyakarta: Millestone.

Bobak, I. M. Dkk. 2017. Buku Ajar Keperawatan Maternitas (terjemahan, edisi. 4), Jakarta: EGC.

Darvill, W. Dkk. 2016. The Puberty Book panduan untuk remaja. Jakarta : PT. Gramadia Pustaka Utama.

Hasbullah, 2017., Belajar Mudah Penelitian untuk Guru, Karyawan dan Peneliti Pemula. Bandung: Alfabeta.

Hasbullah,2017., Belajar Mudah Penelitian untuk Guru, Karyawan dan Peneliti Pemula. Bandung: Alfabeta.

Jones, D. L. 2017. Setiap Wanita. Jakarta: PT. Delapratasa Publisihing

Kartono, K. (2016). Psikologi Wanita: Mengenal Gadis Remaja dan Wanita Dewasa. Bandung: Mandar Maju.

Prastika, D. 2016. Hubungan Indeks Massa Tubuh (IMT) Dengan Usia Menarche Pada Remaja Putri. (online), http://azizahmentariindah.blogspot.com/2 013/06/hubungan-indeksmassa-tubuhimtdengan.html, diakses 12 maret 2015.

Purwoko,2017., Perilaku Hidup Bersih Dan Sehat (PHBS). Nuha Medika. Yogyakarta

Mubarak, 2016., Psikologi Anak Dan Remaja. Jakarta: Balai Pustaka

Manuaba, dkk. 2017. Pengantar Kuliah Obstetri. Jakarta: EGC.

Mansur \& Budiarti,2017, Hubungan Dengan Kebiasaan Mencuci Tangan Dengan Kejadian Diare Pada Anak. Diakses Tanggal 02 Oktober, 2017

Maulana, 2017, Pengaruh Perilaku Cuci Tangan Terhadap Kejadian Diare Pada Siswa SD Negeri Magelang. Magelang. Diakses Tanggal 02 Oktober, 2017

Notoatmodjo, S. 2017. Promosi Kesehatan. Jakarta: Rineka Cipta.

Notoatmodjo, 2017., Tentang Persyaratan Kesehatan Perumahan. Jakarta

Notoatmodjo, 2018., Meningkatkan Kualitas Hidup Wanita Menopause, Medika, Vol. 1, pp. 33-38

Proverawati, M. 2017. Menarche, Menstruasi Penuh Makna. Yogyakarta : Nuha Medika

Pulungan, F. (2016). Pengaruh Fungsi Keluarga Terhadap Pemahaman Remaja Putri Usia Sekolah Dasar Tentang Menarche (online). Di akses dari http://repository.usu.ac.id/bits tream/123456789/34639/5/Ch apter\%20I.pdf tanggal 26 maret 2015

Sarwono,2016, Pengaruh Pendidikan Kesehatan Terhadap Pengetahuan Dan Sikap Cuci Tangan Pakai Sabun Pada Sisiwa SD Negeri 157 Kota Palembang Tahun 2014. Artikel Ilmiah

Santrock, 2016, Kata Dokter, Sehat Setiap Hari Ala @ Blogerdokter. Jakarta. Panda Media

Wiknjosastro H, Dkk. 2017. Ilmu Kandungan. Jakarta: Yayasan Bina Pustaka

JURKESMAS : Jurnal Kesehatan Masyarakat, Vol. 1, No. 1, Juli 2021: 1 - 6 